\title{
Long-term follow-up of mesh-covered stent implantation in patients with ST-segment elevation myocardial infarction
}

\author{
Dariusz Dudek ${ }^{1}$, Artur Dziewierz ${ }^{1}$, Paweł Kleczyński ${ }^{1}$, Dawid Giszterowicz ${ }^{2}$, Tomasz Rakowski ${ }^{1}$, \\ Danuta Sorysz' ${ }^{1}$, Łukasz Rzeszutko', Jacek Legutko' ${ }^{1}$, Stanisław Bartuś ${ }^{1}$, Jacek Dragan², Artur Klecha ${ }^{3}$, \\ Zbigniew Siudak ${ }^{1}$, Krzysztof Żmudka ${ }^{1}$
}

'Department of Interventional Cardiology, Jagiellonian University Medical College, Krakow, Poland

${ }^{2}$ Department of Interventional Cardiology, Nowy Sacz, Poland

${ }^{3}$ Department of Interventional Cardiology, Nowy Targ, Poland

\section{A bstract}

Background: The MGuard stent (a bare-metal stent wrapped externally in a polymer mesh sleeve) was introduced to reduce the risk of distal embolisation and no-reflow phenomenon during percutaneous coronary intervention (PCI) in thrombus containing lesions, including ST-segment elevation myocardial infarction (STEMI). However, data on the long-term performance of the MGuard stent is limited.

Aim: To assess the long-term safety and efficacy of MGuard stent implantation during primary PCI for STEMI.

Methods and results: In this multicentre study, a total of 60 patients with STEMI $\leq 12 \mathrm{~h}$ treated with the MGuard stent were enrolled. Angiographic success of $\mathrm{PCl}$ was achieved in $96.7 \%$, with the final TIMI grade 3 flow in $90.0 \%$ of patients. At six months, the overall rate of major adverse cardiac and cerebrovascular events (MACCE; composite of cardiac death, nonfatal target vessel reinfarction, target lesion revascularisation, and stroke) was $1.7 \%$. A long-term follow-up of the study was successfully performed in 57 patients (mean follow-up of $38.7 \pm 3.1$ months). The long-term cardiac mortality was $7.0 \%$, with a MACCE rate of $8.8 \%$. There was no decrease in the left ventricular ejection fraction and no enlargement of the left ventricle between index and long-term follow-up echocardiogram.

Conclusions: The early safety and efficacy of the MGuard stent was maintained during the long-term follow-up. However, comparative data from ongoing randomised clinical trials are still required to confirm the long-term efficacy of MGuard stent implantation in patients with STEMI.

Key words: primary angioplasty, acute myocardial infarction, stent, mesh, long-term outcomes

Kardiol Pol 2014; 72, 2: 140-145

\section{INTRODUCTION}

The mesh-covered stent (MGuard ${ }^{\mathrm{TM}}$ Coronary Stent System, InspireMD Ltd., Israel) is a bare-metal stent covered with an ultra thin, micron level, flexible mesh sleeve [1,2]. It was introduced to reduce the risk of distal embolisation and no-reflow phenomenon during percutaneous coronary intervention $(\mathrm{PCl})$ in the thrombus containing lesions, i.e. ST-segment elevation myocardial infarction (STEMI) setting and degenerated saphenous vein grafts [1,3-5]. The feasi- bility and short-term efficacy of MGuard stent implantation during primary $\mathrm{PCI}$ for STEMI has been confirmed by previous studies $[2,4,5]$, including the MGuard ${ }^{\mathrm{TM}}$ Coronary Stent System in ST-Elevation Myocardial Infarction - A European Post-Market Clinical Study (MAGICAL) [4]. Recently, the Safety and Efficacy Study of MGuard Stent After a Heart Attack (MASTER) Trial [6] has shown that among patients with STEMI, the mesh-covered stent compared to conventional metal stents resulted in superior rates of epicardial coronary

\section{Address for correspondence:}

Dariusz Dudek, MD, PhD, FESC, Department of Interventional Cardiology, Jagiellonian University Medical College, ul. Kopernika 17, 31-501 Kraków, Poland, tel: +48 1242471 81, fax: +48 1242471 84, e-mail: mcdudek@cyfronet.pl

Received: 02.05.2013 Accepted: 03.09.2013 Available as AoP: 12.09.2013

Copyright (C) Polskie Towarzystwo Kardiologiczne 
flow and complete ST-segment resolution during and after primary $\mathrm{PCl}$. However, limited information is still available as to the long-term efficacy of the MGuard stent.

The purpose of the extended follow-up of the MAGICAL study was to assess the long-term clinical outcomes of patients treated with the MGuard stent during primary PCI for STEMI.

\section{METHODS}

Detailed descriptions of the MAGICAL study protocol and main results have been published previously [4]. Briefly, 60 patients with STEMI $\leq 12 \mathrm{~h}$ were enrolled in four centres in Poland from July 2008 to May 2009. The main clinical exclusion criteria were: contraindications to antiplatelet and/or antithrombotic treatment, known history of chronic renal disease or haemodialysis, cardiopulmonary resuscitation, cardiogenic shock, and left ventricular ejection fraction (LVEF) $<30 \%$. The main angiographic exclusion criteria were: presence of excessive vessel tortuosity, diffuse disease or severe lesion/vessel calcification, left main stenosis $>60 \%$, saphenous vein graft stenosis, in-stent thrombosis, and bifurcation lesion with side-branch $>1.5 \mathrm{~mm}$. The use of atherectomy and/or thrombectomy catheters or/and embolic protection devices was not permitted before stent implantation. After enrollment of 30 patients, the protocol of the study was changed and the use of simple aspiration catheters before stenting was at the discretion of the operator.

\section{Treatment strategy}

In all patients, a loading dose of acetylsalicylic acid (ASA) and clopidogrel (600 mg PO) was given. The choice of antithrombin (unfractionated heparin or bivalirudin) and glycoprotein (GP) IIb/IIla inhibitor was at the discretion of the operator. In all patients, primary $\mathrm{PCl}$ with MGuard stent implantation was performed. Direct implantation of the MGuard stent followed by post-dilatation was allowed only if there was adequate visualisation of the distal vessel following wiring of the vessel. If the distal coronary vessel was not visualised with wiring, predilatation with a $\leq 2.0 \mathrm{~mm}$ balloon using low pressures was recommended. The use of simple aspiration catheters was permitted only in the last 30 patients. Dual antiplatelet therapy was recommended for 12 months (ASA 75 mg PO daily, clopidogrel 75 mg PO daily). Adjunctive drugs were used in compliance with the current guidelines for STEMI management.

\section{Clinical assessment}

The primary angiographic and electrocardiographic outcomes have been published previously [4]. In the MAGICAL study, patients were followed for six months for cardiovascular events, all-cause and cardiac death, reinfarction, stent thrombosis, repeat target lesion revascularisation (TLR) and target vessel revascularisation (TVR), and stroke. Following the original protocol conclusion, an extended follow-up of the
MAGICAL study was approved by the Jagiellonian University bioethics committee in Krakow, Poland and conducted. In April 2012, patients were contacted again and data on cardiovascular events occurrence beyond the original six-month follow-up was collected. Follow-up information was obtained by telephone interview with surviving patients, or family members using a structured questionnaire. If possible, patients were asked to come for an office visit and echocardiogram. In the case of event, medical records and angiograms were collected from patients or the relevant medical centres. Major adverse cardiac and cerebrovascular events (MACCE) were defined as a composite of cardiac death, nonfatal target vessel reinfarction, TLR, and stroke. Major adverse cardiac events (MACE) were defined as composite of cardiac death, nonfatal target vessel reinfarction, and TLR. Events were reported in hierarchical order. Stent thrombosis was defined according to the Academic Research Consortium criteria [7]. All clinical events were adjudicated by an independent clinical events committee using original source documents. Data quality and completeness were monitored.

\section{Statistical analysis}

Results were presented as numbers of patients (percentages) or mean \pm standard deviation where applicable. Cumulative cardiac mortality and MACCE rates during follow-up were calculated with the Kaplan-Meier method. Differences in the LVEF and left ventricular end-diastolic dimension between index and follow-up echocardiogram were analysed with a paired sample t-test. All tests were two-tailed, and a $p$ value $<0.05$ was considered statistically significant. All statistical analysis was performed using SPSS 15.0 (SPSS, Inc., Chicago, IL, USA).

\section{RESULTS}

Sixty patients were enrolled into the study. The main results of the study, including the primary angiographic and electrocardiographic outcomes, have been published previously [4]. Baseline characteristics and invasive treatment details are shown in Table 1. All patients were pretreated with a clopidogrel loading dose of $600 \mathrm{mg}$, and 59 (98.3\%) patients received an ASA loading dose of $325 \mathrm{mg}$ before angiography. In most patients $(65.0 \%)$, the right coronary artery was identified as the infarct-related artery (Table 1). Patent infarct-related artery at baseline - Thrombolysis In Myocardial Infarction (TIMI) grade 2 or 3 flow was found in 22 (36.6\%) patients. In all patients, a weight-adjusted dose of unfractionated heparin was given. Additionally, in 24 (40.0\%) patients a GP Ilb/Illa inhibitor (abciximab) was used during primary $\mathrm{PCl}$. The mean time-delay from chest pain onset to stent implantation was $269 \pm 155 \mathrm{~min}$. The angiographic success of $\mathrm{PCl}$ was achieved in 58 (96.7\%) with the final TIMI grade 3 flow in 54 (90.0\%) patients.

No ischaemic complications were observed during the index hospital stay. Clopidogrel and ASA were prescribed at 
Table 1. Baseline demographics and invasive treatment details

\begin{tabular}{lc|} 
Variable & $\mathbf{N}=60$ \\
\hline Males & $44(73.0 \%)$ \\
Age [years] & $61.6 \pm 9.6$ \\
Arterial hypertension & $32(53.3 \%)$ \\
Hyperlipidaemia & $31(51.7 \%)$ \\
Diabetes mellitus & $5(8.3 \%)$ \\
Previous MI & $3(5.0 \%)$ \\
Previous PCl & $2(3.3 \%)$ \\
Previous CABG & $0(0.0 \%)$ \\
Current smoker & $33(55.0 \%)$ \\
Heart rate on admission [bpm] & $76.9 \pm 14.2$ \\
Systolic BP on admission [mm Hg] & $143.9 \pm 24.6$ \\
Diastolic BP on admission [mm Hg] & $76.9 \pm 14.2$ \\
Infarct related artery: & \\
Left anterior descending artery & $17(28.3 \%)$ \\
Circumflex artery & $4(6.7 \%)$ \\
Right coronary artery & $39(65.0 \%)$ \\
Thrombus presence & $51(85.0 \%)$ \\
Aspiration catheter used & $11(18.3 \%)$ \\
Predilatation performed & $37(61.7 \%)$ \\
Postdilatation performed & $32(53.3 \%)$ \\
\hline P - blood pressure; CABG & \\
\hline
\end{tabular}

$\mathrm{BP}$ - blood pressure; CABG - coronary artery bypass grafting; $\mathrm{MI}$ - myocardial infarction; $\mathrm{PCl}$ - percutaneous coronary intervention

discharge in all patients. During six-month follow-up, there was one $(1.7 \%)$ TVR and one $(1.7 \%)$ ischaemic stroke. In the patient who needed TVR, an additional stent was implanted in the segment other than that treated during the index procedure. The study stent was patent and without significant stenosis.

By protocol definition, six-month rates of MACCE and MACE were $1.7 \%$ and $0 \%$, respectively. A long-term follow-up of the MAGICAL study was successfully performed in 57 (95\%) patients. Three (5\%) patients were lost to follow-up. The mean follow-up was $38.7 \pm 3.1$ months (range 34.2-44.3 months). Beyond the six months, there was one $(1.8 \%)$ TVR and one $(1.8 \%)$ TLR, without nonfatal target vessel reinfarction. Additionally, there was one (1.8\%) non-cardiac death and four $(7.0 \%)$ cardiac deaths. However, one of the cardiac deaths occurred in a patient with a previous stroke event, and a second in a patient undergoing TVR. Total three-year cardiac mortality was low $-7.0 \%$. There was no definite or probable stent thrombosis (according to the Academic Research Consortium criteria). Finally, there were five (8.8\%) MACE and five (8.8\%) MACCE. Kaplan-Meier curves for cardiac death and MACCE are shown in Figure 1. Long-term echocardiography was performed in 32 patients. There was no significant decrease in the LVEF (index vs. follow-up examination: $55.1 \pm 11.5 \%$ vs. $57.3 \pm 8.6 \%$; $p=0.17$ ) and no enlargement of the left ventricle (the left ventricular end-diastolic dimension: $5.1 \pm 0.4 \mathrm{~cm}$ vs. $5.2 \pm 0.5 \mathrm{~cm}$; $\mathrm{p}=0.22$ ) between index and follow-up echocardiogram. No differences in baseline characteristics and angiographic parameters were observed between patients with and without follow-up echocardiography.

\section{DISCUSSION}

In this prospective series of patients with STEMI, the early safety and efficacy of MGuard stent implantation was maintained during the long-term follow-up and the observed MACCE rate was low $-8.8 \%$.

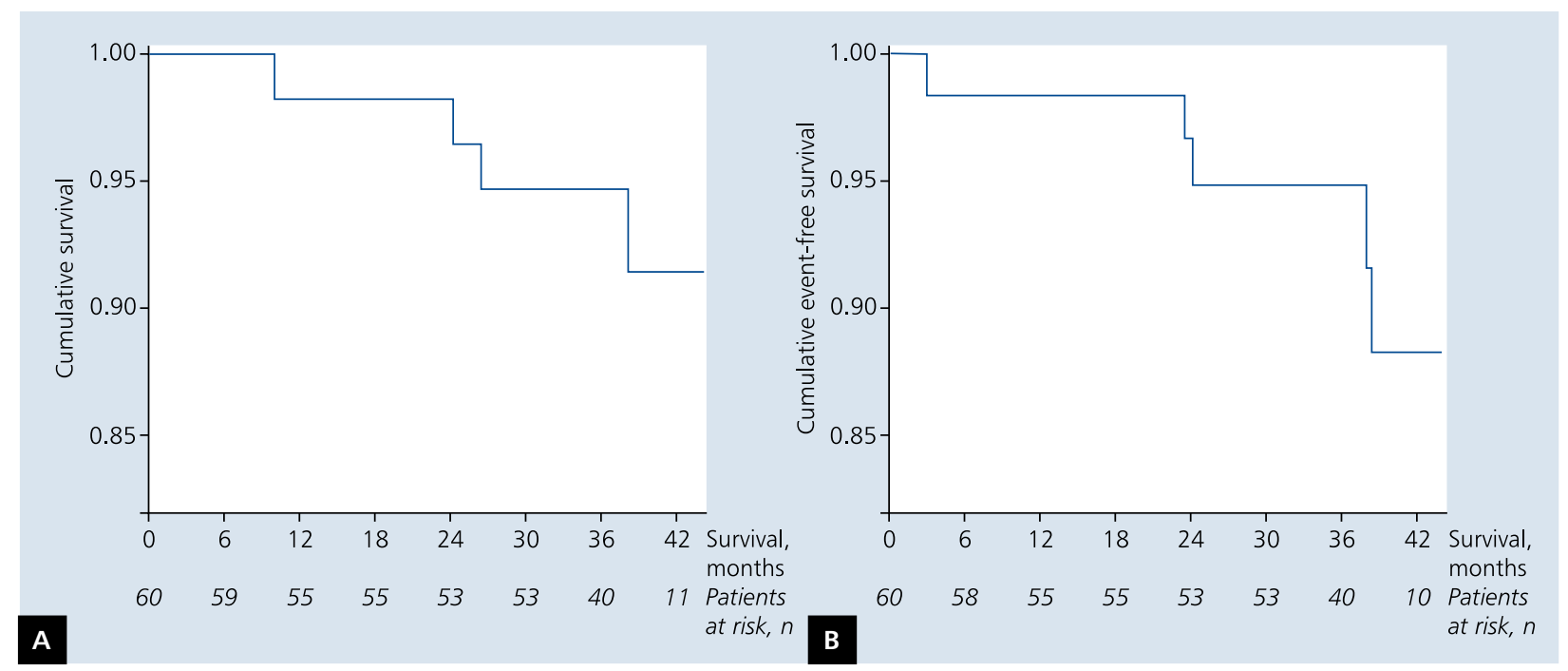

Figure 1. Kaplan-Meier curves for cardiac deaths (A) and major adverse cardiac and cerebrovascular events (B) 
The MGuard stent is designed to decrease the risk of distal embolisation during primary PCI for STEMI. In the MASTER study, its use compared to standard metal stents (bare-metal stent or drug-eluting stent) implantation in patients undergoing primary $\mathrm{PCl}$ resulted in significantly higher rates of TIMI grade 3 flow, and complete ST-segment resolution after the procedure [6]. Importantly, the benefits in terms of improved ST-segment resolution related to MGuard stent use were observed in both patients with and without prior aspiration thrombectomy before stent implantation. As reported previously by our group [4], the rates of TIMI grade 3, myocardial blush grade 3, and complete ST-segment resolution after $\mathrm{PCI}$ were comparable to those observed in the MASTER trial (MAGICAL vs. MASTER: TIMI grade $3-90.0 \%$ vs. 91.8\%; myocardial blush grade $3-73.3 \%$ vs. $74.2 \%$; ST-segment resolution $\geq 70 \%-61.4 \%$ vs. $57.8 \%$ ) [6].

The achievement of early and sustained reperfusion not only on epicardial, but primarily on microcirculatory, level may lead to improved long-term survival, as the optimal myocardial perfusion is associated with improved patient outcomes [8-10]. In the MASTER trial, mortality at 30 days was greater in patients not achieving complete ST-segment resolution after $\mathrm{PCl}$, resulting in a strong trend towards reduced cardiac mortality in patients in whom the MGuard stent was implanted compared to a control stent [6]. This benefit was maintained during a six-month follow-up (MGuard vs control: $0.5 \%$ vs. $2.8 \% ; p=0.056)$. As in our study, no deaths during a 30-day follow-up in patients treated with the MGuard stent were noted. Similar favourable clinical outcomes of patients with STEMI treated with the MGuard stent were reported by Piscione et al. [5].

However, data on the long-term performance of the MGuard stent is rather limited. In a group of 41 patients treated with the MGuard stent during $\mathrm{PCl}$ in old degenerated venous grafts and/or native coronaries culprit lesions in patients experiencing acute coronary syndromes, the total MACE rate at a mean follow-up of 20 months was $24.4 \%$, with an all-cause mortality rate of $2.4 \%$ [11]. Data presented by Piscione et al. [5] during the TCT 2010 meeting for 89 non-shock patients with STEMI revealed all-cause and cardiac mortality rates for two-year follow-up of $9.0 \%$ and $2.2 \%$, respectively. Our MACE and MACCE rates were slightly lower than those reported in the Harmonizing Outcomes with Revascularisation and Stents in Acute Myocardial Infarction (HORIZONS-AMI) trial for three-year follow-up, although with greater rates of all-cause and cardiac death [12]. In contrast, the long-term event rates were lower than those reported in large multicentre registries for patients treated with stent during primary PCI for STEMI [13-15].

The extent of restenosis within the MGuard stent cannot be assessed, as a control angiography was not routinely performed in our study. In the first-in-man study, the rate of TVR for the MGuard stent was $11.1 \%$, with a mean late loss of $0.372 \pm 0.23 \mathrm{~mm}$ and a mean per cent diameter stenosis of $30.6 \%$ at control angiogram performed six months after stent implantation [3]. Despite the lack of an antiproliferative agent, the rate of TLR for the MGuard stent during the three-year follow-up in our study was very low (1.7\%). The risk of ischaemic TVR in patients after STEMI is potentially lower than in patients without infarction, as the infracted territory may be clinically silent when restenosis occurs. So, we can assume a slightly greater rate of TLR or TVR when a routine control angiogram is carried out [16]. Similarly, Piscione at al. [5] reported rates of $3.4 \%$ and $1.1 \%$ for TVR and definite stent thrombosis at two years, respectively. In the MASTER study, there was an increased risk of TLR (MGuard vs. control: $4.8 \%$ vs. $1.0 \%$; $p=0.02)$ and TVR $(6.2 \%$ vs. $1.0 \% ; p<0.01)$ at six months in patients treated with the MGuard stent compared to the available bare-metal stents or drug-eluting stents. However, the observed rate of restenosis was comparable to that reported for bare-metal stents in previous studies [12].

One-year results of the MASTER study will provide additional data on the long-term performance of the MGuard stent. A second study, the MGuard vs. bare-metal stents plus manual thrombectomy in STEMI patients (GUARDIAN, NCT01124942), is going to compare the MGuard stent alone vs. thrombus aspiration with bare-metal stent implantation [17]. The results of these studies may allow assessment of the competing benefits (improved myocardial reperfusion) and risks (potentially higher risk of restenosis compared to drug-eluting stents) of the MGuard stent compared to conventional metal stents.

\section{Limitations of the study}

The main limitation of the present study is a small sample and non-randomised study design. The study population was preselected based on inclusion and exclusion criteria, and thus may be a lower risk group. In addition, three (5\%) patients were lost to follow-up, and the control echocardiogram was performed only in 32 patients. No routine control angiogram was performed. On the other hand, this is the second, large cohort of patients with STEMI treated with MGuard stent implantation during primary $\mathrm{PCl}$ with long-term clinical outcome data available.

\section{CONCLUSIONS}

The early safety and efficacy of the MGuard stent was maintained during the long-term follow-up. However, comparative data from ongoing randomised clinical trials is still required to confirm the long-term efficacy of MGuard stent implantation in patients with STEMI.

This study was sponsored by InspireMD Ltd., Israel.

Conflict of interest: Dariusz Dudek, Jacek Legutko, Stanisław Bartuś - research grant from InspireMD. 


\section{References}

1. Kaluski E, Tsai S, Klapholz M. Coronary stenting with MGuard: from conception to human trials. Cardiovasc Revasc Med, 2008; 9: 88-94.

2. Dziewierz A, Dudek D. Advantages of MGuard coronary stent system. Minerva Cardioangiol, 2012; 60: 33-40.

3. Kaluski E, Hauptmann KE, Muller R et al. Coronary stenting with MGuard: first-in-man trial. J Invasive Cardiol, 2008; 20: 511-515.

4. Dudek D, Dziewierz A, Rzeszutko L et al. Mesh covered stent in ST-segment elevation myocardial infarction. EuroIntervention, 2010; 6: 582-589.

5. Piscione F, Danzi GB, Cassese S et al. Multicentre experience with MGuard net protective stent in ST-elevation myocardial infarction: safety, feasibility, and impact on myocardial reperfusion. Catheter Cardiovasc Interv, 2010; 75: 715-721.

6. Stone GW, Abizaid A, Silber S et al. Prospective, Randomized, Multicenter Evaluation of a Polyethylene Terephthalate Micronet Mesh-Covered Stent (MGuard) in ST-segment elevation myocardial infarction: the MASTER Trial. J Am Coll Cardiol, 2012; 60: 1975-1984.

7. Cutlip DE, Windecker S, Mehran R et al. Academic Research Consortium. Clinical end points in coronary stent trials: a case for standardized definitions. Circulation, 2007; 115: 2344-2351.

8. Stone GW, Peterson MA, Lansky AJ et al. Impact of normalized myocardial perfusion after successful angioplasty in acute myocardial infarction. J Am Coll Cardiol, 2002; 39: 591-597.

9. Henriques JP, Zijlstra F, van't Hof AW et al. Angiographic assessment of reperfusion in acute myocardial infarction by myocardial blush grade. Circulation, 2003; 107: 2115-2119.

10. Fokkema ML, Vlaar PJ, Svilaas T et al. Incidence and clinical consequences of distal embolization on the coronary angiogram after percutaneous coronary intervention for ST-elevation myocardial infarction. Eur Heart J, 2009; 30: 908-915.

11. Grube E, Hauptmann KE, Muller R et al. Coronary stenting with MGuard: extended follow-up of first human trial. Cardiovasc Revasc Med, 2011; 12: 138-146.

12. Stone GW, Witzenbichler B, Guagliumi G et al. Heparin plus a glycoprotein IIb/IIIa inhibitor versus bivalirudin monotherapy and paclitaxel-eluting stents versus bare-metal stents in acute myocardial infarction (HORIZONS-AMI): final 3-year results from a multicentre, randomised controlled trial. Lancet, 2011; 377: 2193-2204.

13. Campo G, Saia F, Percoco G, et al. Long-term outcome after drug eluting stenting in patients with ST-segment elevation myocardial infarction: data from the REAL registry. Int J Cardiol, 2010; 140: 154-160.

14. Dziewierz A, Siudak Z, Rakowski T et al. Drug-eluting versus bare-metal stents in ST-segment elevation myocardial infarction: a mortality analysis from the EUROTRANSFER Registry. Clin Res Cardiol, 2011; 100: 139-145.

15. Kübler P, Jankowska EA, Ferenc M et al. Comparison of drug-eluting stents to bare-metal stents in ST-elevation myocardial infarction in long-term follow-up. Kardiol Pol, 2013; 71: 25-31.

16. Stone GW, Parise H, Witzenbichler B et al. Selection criteria for drug-eluting versus bare-metal stents and the impact of routine angiographic follow-up: 2-year insights from the HORIZONS-AMI (Harmonizing Outcomes With Revascularization and Stents in Acute Myocardial Infarction) trial. J Am Coll Cardiol, 2010; 56: 1597-1604.

17. Cassese S, Esposito G, Mauro C et al. MGUard versus bAre-metal stents plus manual thRombectomy in ST-elevation myocarDial infarction pAtieNts-(GUARDIAN) trial: study design and rationale. Catheter Cardiovasc Interv, 2012; 79: 1118-1126. 


\title{
Obserwacja odległa implantacji stentu pokrytego siateczką u pacjentów z zawałem serca $z$ uniesieniem odcinka ST
}

\author{
Dariusz Dudek ${ }^{1}$, Artur Dziewierz1, Paweł Kleczyński ${ }^{1}$, Dawid Giszterowicz ${ }^{2}$, Tomasz Rakowski ${ }^{1}$, \\ Danuta Sorysz ${ }^{1}$, Łukasz Rzeszutko ${ }^{1}$, Jacek Legutko ${ }^{1}$, Stanisław Bartuś ${ }^{1}$, Jacek Dragan², Artur Klecha ${ }^{3}$, \\ Zbigniew Siudak ${ }^{1}$, Krzysztof Żmudka ${ }^{1}$
}

'Il Klinika Kardiologii, Instytut Kardiologii, Uniwersytet Jagielloński, Collegium Medicum, Kraków

${ }^{2}$ Centrum Kardiologii Inwazyjnej, Elektroterapii i Angiologii, Nowy Sącz

${ }^{3}$ Centrum Kardiologii Inwazyjnej, Elektroterapii i Angiologii, Nowy Targ

\section{Streszczenie}

Wstęp: Stent MGuard (stent stalowy pokryty z zewnątrz poliuretanową siateczką) został wprowadzony w celu redukcji ryzyka zatorowania obwodowego i zjawiska braku przepływu (no-reflow) w trakcie zabiegu angioplastyki wieńcowej (PCI) w zakresie zmiany zawierającej materiał zakrzepowy, w tym w zawale serca z uniesieniem odcinka ST (STEMI). Dane dotyczące wyników odległych implantacji stentu MGuard są jednak ograniczone.

Cel: Celem pracy była ocena odległego bezpieczeństwa i skuteczności implantacji stentu MGuard w trakcie zabiegu pierwotnej PCI w STEMI.

Metody i wyniki: Do tego wieloośrodkowego badania włączono łącznie 60 pacjentów ze STEMI i czasem trwania objawów poniżej 12 h, leczonych stentem MGuard. Sukces angiograficzny zabiegu osiągnięto u 96,7\% osób, przy pełnym napływie obwodowym w zakresie tętnicy odpowiedzialnej za zawał (TIMI 3) stwierdzanym w 90\% przypadków. W okresie 6-miesięcznej obserwacji łączna częstość ciężkich zdarzeń sercowych i naczyniowo-mózgowych (MACCE; łącznie zgon z przyczyn sercowych, ponowny zawał niezakończony zgonem, ponowna rewaskularyzacja zmiany poddawanej angioplastyce i udar mózgu) wyniosła 1,7\%. Obserwacja odległa badania została przeprowadzona u 57 pacjentów (średni okres obserwacji $38,7 \pm 3,1$ miesiąca). Odległa śmiertelność z przyczyn sercowych wyniosła 7\%, z częstością MACCE równą 8,8\%. Nie zaobserwowano spadku wartości frakcji wyrzutowej lewej komory czy też powiększenia jamy serca między echokardiogramem wyjściowym a wykonanym w ramach obserwacji odległej.

Wnioski: Wczesne bezpieczeństwo i skuteczność stentu MGuard utrzymywało się w okresie obserwacji odległej. Nadal potrzebne są dane z trwających badań randomizowanych w celu potwierdzenia odległej skuteczności implantacji stentu MGuard u pacjentów ze STEMI.

Słowa kluczowe: pierwotna angioplastyka wieńcowa, zawał serca, stent, siateczka, rokowanie odległe

Kardiol Pol 2014; 72, 2: 140-145

\section{Adres do korespondencji:}

prof. UJ, dr hab. n med. Dariusz Dudek, II Klinika Kardiologii, Instytut Kardiologii, Uniwersytet Jagielloński, Collegium Medicum, ul. Kopernika 17, $31-501$ Kraków, tel: +48 1242471 81, faks: +48 1242471 84, e-mail: mcdudek@cyfronet.pl

Praca wpłynęła: 02.05.2013 r. Zaakceptowana do druku: 03.09 .2013 r.

Data publikacji AoP: 12.09.2013 r 